\title{
High-Pressure Diels-Alder Approach to Natural Kainic Acid
}

Sushil K. Pandey, Arturo Orellana, Andrew E. Greene, and Jean-François Poisson*

Chimie Recherche (LEDSS), Université Joseph Fourier, 38041 Grenoble, France

jean-francois.poisson@ujf-grenoble.fr

\section{SUPPORTING INFORMATION}

Reactions were generally carried out under argon in oven-dried glassware. Standard inert atmosphere techniques were used in handling all air and moisture sensitive reagents. Dry THF was obtained by filtration through activated molecular sieves and dry toluene, diethyl ether, and $\mathrm{CH}_{2} \mathrm{Cl}_{2}$ by filtration through activated aluminium oxide. DMF and pyridine were distilled under reduced pressure from calcium hydride. Thin-layer chromatography was performed on silica gel sheets $(0.2 \mathrm{~mm})$, which were visualized under ultraviolet light and by heating the plate after treatment with phosphomolybdic acid in ethanol, a $p$-anisaldehyde staining solution $(80 \mathrm{~mL}$ of $95 \%$ ethanol, $2.9 \mathrm{~mL}$ of sulfuric acid, $0.86 \mathrm{~mL}$ of acetic acid, 2.1 $\mathrm{mL}$ of $p$-anisaldehyde), nihydrin in ethanol, ceric ammonium molybdate in ethanol, or basic, aqueous $\mathrm{KMnO}_{4}$. Silica gel $(0.040-0.063 \mathrm{~mm})$ was employed for flash column chromatography. Melting points were obtained on a Buchi melting point apparatus and are uncorrected. Optical rotations were determined with a Perkin-Elmer 341 polarimeter. A Nicolet Impact 400 FTIR spectrometer was used to record infrared spectra. ${ }^{1} \mathrm{H}$ NMR and ${ }^{13} \mathrm{C}$ NMR spectra were recorded on either a Bruker AV 300 or a Varian 500 apparatus. All shifts for ${ }^{1} \mathrm{H}$ spectra have been referenced to the residual solvent peak and are reported in ppm. When ambiguous, proton and carbon assignments were established using COSY, HMQC, and/or DEPT experiments. Mass spectra were recorded using either DCI (ammonia/isobutane 63/37) or ESI techniques. Microanalyses were performed by the analytical service of the LEDSS.

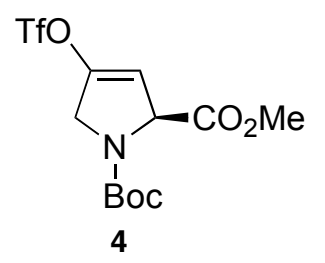

(S)-1-tert-butyl 2-methyl 4-(trifluoromethylsulfonyloxy)-2H-pyrrole-1,2(5H)dicarboxylate (4). To a stirred solution of NaHMDS (1.0 M in THF, $33.9 \mathrm{~mL}, 33.9 \mathrm{mmol})$ in 
THF $(20 \mathrm{~mL})$ at $-78{ }^{\circ} \mathrm{C}$ was added slowly the ketone derived from $3(7.50 \mathrm{~g}, 30.8 \mathrm{mmol})$ in THF $(15 \mathrm{~mL})$. The reaction mixture was stirred for $30 \mathrm{~min}$ and then treated over $15 \mathrm{~min}$ with a solution of $\operatorname{PhNTf}_{2}(12.12 \mathrm{~g}, 33.9 \mathrm{mmol})$ in THF $(25 \mathrm{~mL})$. The resulting mixture was stirred for $1.5 \mathrm{~h}$ at $-78{ }^{\circ} \mathrm{C}$, allowed to warm to $0{ }^{\circ} \mathrm{C}$, and then quenched by the addition of water $(25 \mathrm{~mL})$. The mixture was extracted with ether, which was washed with brine and dried over $\mathrm{Na}_{2} \mathrm{SO}_{4}$. Evaporation of the solvent under reduced pressure and purification of the residue on silica gel (15:85 AcOEt-pentane) afforded $9.85 \mathrm{~g}(85 \%)$ of triflate 4 : $[\alpha]^{20}{ }_{\mathrm{D}}-125.2$ (c 1.1, $\mathrm{CHCl}_{3}$ ); IR (film) 1762, 1720, 1637, 1213, 1140, 1119, $1000 \mathrm{~cm}^{-1} ;{ }^{1} \mathrm{H}$ NMR (300 $\mathrm{MHz}, \mathrm{CDCl}_{3}, 2$ rotamers) 5 5.74-5.72 and 5.69-5.67 (2 m, 1H), 5.05-5.03 and 5.00-4.97 (2 m, 1H), 4.39-4.25 (m, 2H), 3.75 (s, 3H), 1.46 and $1.41(2 \mathrm{~s}, 9 \mathrm{H}) ;{ }^{13} \mathrm{C} \mathrm{NMR}\left(75 \mathrm{MHz}, \mathrm{CDCl}_{3}, 2\right.$ rotamers) $\delta 169.5,169.2,153.1,152.5,146.2,145.7,(124.8,120.5,116.3,112.0) \mathrm{CF}_{3}, 111,3$,

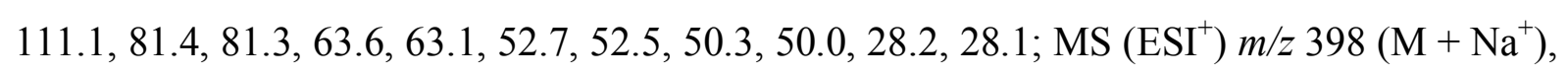
321, 307 (100\%); HRMS (LTQ-Orbitrap, ESI) Calcd. for $\mathrm{C}_{12} \mathrm{H}_{16} \mathrm{~F}_{3} \mathrm{NO}_{7} \mathrm{SNa}$; 398.0497. Found $398.0492\left(\mathrm{M}+\mathrm{Na}^{+}\right)$.

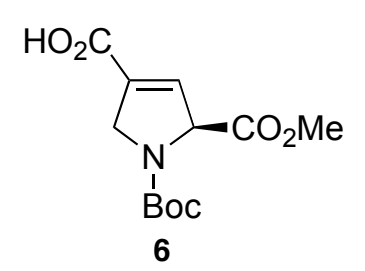

(S)-1-(tert-Butoxycarbonyl)-5-(methoxycarbonyl)-2,5-dihydro-1H-pyrrole-3-

carboxylic Acid (6). To a solution of triflate 4 (11.88 g, $31.65 \mathrm{mmol})$ in 8:2 THF- $\mathrm{H}_{2} \mathrm{O}(80$ $\mathrm{mL})$ at $20{ }^{\circ} \mathrm{C}$ was added $\left(\mathrm{PPh}_{3}\right)_{4} \mathrm{Pd}(0.915 \mathrm{~g}, 0.79 \mathrm{mmol})$, and $\mathrm{CO}$ was then bubbled through using a needle attached to a $\mathrm{CO}$-filled balloon for $20 \mathrm{~min}$. A slightly positive pressure of $\mathrm{CO}$ was maintained for $1 \mathrm{~h}$, after which $\mathrm{CO}$ was again bubbled for $5 \mathrm{~min}$ through the solution, which was then stirred for another $2 \mathrm{~h}$ under positive pressure of $\mathrm{CO}$. After replacing the $\mathrm{CO}$ with argon, water was added and the mixture was extracted with ether, which was in turn extracted with aqueous $\mathrm{NaHCO}_{3}$. This basic aqueous phase was acidified to $\mathrm{pH} 2$ with $2 \mathrm{~N}$ $\mathrm{HCl}$ and then extracted with ether, which was washed with brine, dried over $\mathrm{Na}_{2} \mathrm{SO}_{4}$, and concentrated to afford $8.05 \mathrm{~g}(94 \%)$ of acid ester 6 as a white solid: $\mathrm{mp} 110-112{ }^{\circ} \mathrm{C} ;[\alpha]^{20}{ }_{\mathrm{D}}^{-}$ 202.5 (c 0.7, $\mathrm{CHCl}_{3}$ ); IR (film) 1737, 1720, 1632, 1175, 1087, $996 \mathrm{~cm}^{-1} ;{ }^{1} \mathrm{H} \mathrm{NMR} \mathrm{(300} \mathrm{MHz,}$ $\mathrm{CDCl}_{3}, 2$ rotamers) $\delta 8.51$ (br s, $\left.1 \mathrm{H}\right), 6.68-6.66$ and 6.63-6.61 $(2 \mathrm{~m}, 1 \mathrm{H}), 5.23-5.19$ and 5.12$5.08(2 \mathrm{~m}, 1 \mathrm{H}), 4.41-4.34(\mathrm{~m}, 2 \mathrm{H}), 3.72(\mathrm{~s}, 3 \mathrm{H}), 1.44$ and $1.38(2 \mathrm{~s}, 9 \mathrm{H}) ;{ }^{13} \mathrm{C}$ NMR $(75 \mathrm{MHz}$, $\mathrm{CDCl}_{3}, 2$ rotamers) $\delta 169.3,169.0,165.6,165.5,153.8,153.2,135.6,135.4,134.7,134.6$, 81.1, 67.3, 66.9, 52.7, 52.6, 52.2, 51.9, 28.2, 28.1; MS (DCI, $\mathrm{NH}_{3} /$ isobutane) $m / z 270$ (100\%), 
224, 133. Anal. Calcd. for $\mathrm{C}_{12} \mathrm{H}_{17} \mathrm{NO}_{6}$ : C, 53.13; H, 6.32; N, 5.16. Found: C, 52.79; H, 6.18; N, 5.20.

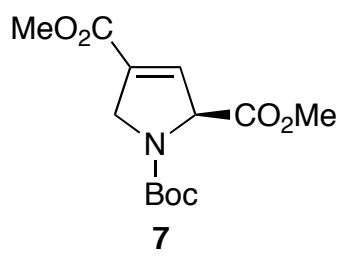

(S)-1-tert-Butyl 2,4-Dimethyl $1 \mathrm{H}$-Pyrrole-1,2,4(2H,5H)-tricarboxylate (7). To a solution of the above acid ester $6(6.26 \mathrm{~g}, 23.1 \mathrm{mmol})$ in ether $(60 \mathrm{~mL})$ at $0{ }^{\circ} \mathrm{C}$, was added ethereal diazomethane (ca. $0.3 \mathrm{M}, 88 \mathrm{~mL}, 26 \mathrm{mmol}$ ). After $15 \mathrm{~min}$, the solvent was removed under reduced pressure and the crude product was purified by chromatography on silica gel (25:75 AcOEt-pentane) to afford $6.20 \mathrm{~g} \mathrm{(94 \% )}$ of diester 7 as a white solid: $\mathrm{mp} 41-43{ }^{\circ} \mathrm{C}$; $[\alpha]^{20}{ }_{\mathrm{D}}-214.2\left(c 0.6, \mathrm{CHCl}_{3}\right)$; IR (film) 1762, 1730, 1709, 1245, 1168, 1091, $1003 \mathrm{~cm}^{-1} ;{ }^{1} \mathrm{H}$ NMR (300 MHz, $\mathrm{CDCl}_{3}, 2$ rotamers) $\delta$ 6.64-6.61 and 6.60-6.57 (2 m, 1H), 5.21-5.17 and 5.13-5.09 $(2 \mathrm{~m}, 1 \mathrm{H}), 4.45-4.37(\mathrm{~m}, 2 \mathrm{H}), 3.78(\mathrm{~s}, 3 \mathrm{H}), 3.76$ and $3.75(2 \mathrm{~s}, 3 \mathrm{H}), 1.48$ and $1.43(2$ $\mathrm{s}, 9 \mathrm{H}) ;{ }^{13} \mathrm{C} \mathrm{NMR}\left(75 \mathrm{MHz}, \mathrm{CDCl}_{3}, 2\right.$ rotamers) $\delta 169.3,168.9,162.4,162.3,153.4,152.7$, 134.7, 134.6, 134.0, 133.9, 80.5, 80.4, 67.0, 66.7, 52.4, 52.3, 52.2, 52.0, 51.82, 51.80, 28.1, 28.0; $\mathrm{MS}_{\left(\mathrm{ESI}^{+}\right)} \mathrm{m} / z 292\left(\mathrm{M}+\mathrm{Li}^{+}\right), 239$ (100\%). Anal. Calcd. for $\mathrm{C}_{13} \mathrm{H}_{19} \mathrm{NO}_{6}$ : C, 54.73; $\mathrm{H}$, 6.71; N, 4.91. Found: C, 54.84; H, 6.82; N, 4.87 .

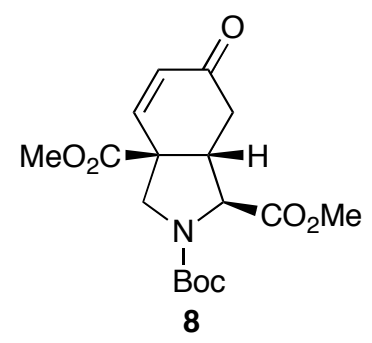

(1S)-2-tert-Butyl

1,3a-Dimethyl

6-Oxo-3,3a-dihydro-1H-isoindole1,2,3a(6H,7H,7aH)-tricarboxylate (8). A solution of diester 7 (4.72 g, $16.6 \mathrm{mmol})$ and Danishefsky's diene $(4.84 \mathrm{~mL}, 24.9 \mathrm{mmol})$ in dichloromethane $(0.5 \mathrm{~mL})$ was placed in a teflon ampoule, which was then closed (completely filled, no air bubbles). The ampoule was then subjected to a pressure of $15 \mathrm{kbar}$ for $72 \mathrm{~h}$, whereupon the pressure was released and the reaction mixture was added to THF $(25 \mathrm{~mL})$ and saturated aqueous $\mathrm{KHSO}_{4}(20 \mathrm{~mL})$. After being stirred for 30 minutes, the mixture was extracted with ether, which was washed with brine and dried over $\mathrm{Na}_{2} \mathrm{SO}_{4}$. Evaporation of the solvent under reduced pressure and purification of the residue by chromatography on silica gel (35:65 AcOEt-pentane) afforded 
$1.46 \mathrm{~g}(23 \%)$ of the intermediate $\beta$-methoxy ketone and $3.63 \mathrm{~g}(62 \%)$ of the desired enone diester (8). The former was converted in $80 \%$ yield to the latter on refluxing in toluene in the presence of a catalytic amount of DBU for $7 \mathrm{~h}$. Enone diester 8 (90\% ee by HPLC): $[\alpha]^{20}{ }_{\mathrm{D}}-$ 6.6 (c 1.2, $\mathrm{CHCl}_{3}$ ); IR (film) 1755, 1735, 1701, 1681, 1158, 1128, 1074, $1020 \mathrm{~cm}^{-1} ;{ }^{1} \mathrm{H}$ NMR $\left(300 \mathrm{MHz}, \mathrm{CDCl}_{3}, 2\right.$ rotamers) $\delta$ 6.74-6.67 (m, 1H), $6.16(\mathrm{~d}, J=10.0 \mathrm{~Hz}, 1 \mathrm{H}), 4.02-3.77(\mathrm{~m}$, $3 \mathrm{H}), 3.75(\mathrm{~s}, 3 \mathrm{H}), 3.74(\mathrm{~s}, 3 \mathrm{H}), 3.28-3.23(\mathrm{~m}, 1 \mathrm{H}), 2.88$ and $2.82(2 \mathrm{~d}, J=5.4 \mathrm{~Hz}, 1 \mathrm{H}), 2.71-$ $2.61(\mathrm{~m}, 1 \mathrm{H}), 1.44$ and $1.37(2 \mathrm{~s}, 9 \mathrm{H}) ;{ }^{13} \mathrm{C} \mathrm{NMR}\left(75 \mathrm{MHz}, \mathrm{CDCl}_{3}, 2\right.$ rotamers $) \delta 194.6,194.3$, $171.6,171.3,169.6,169.5,153.1,152.6,146.2,145.8,131.9,131.7,80.6,62.4,62.2,55.5$, 55.1, 52.9, 52.8, 52.2, 52.0, 51.8, 51.0, 44.6, 43.7, 35.5, 28.0, 27.8; MS (ESI $\left.{ }^{+}\right) \mathrm{m} / z 376(\mathrm{M}+$ $\left.\mathrm{Na}^{+}, 100 \%\right), 354\left(\mathrm{MH}^{+}\right)$. Anal. Calcd. for $\mathrm{C}_{17} \mathrm{H}_{23} \mathrm{NO}_{7}$ : C, 57.78; H, 6.56; N, 3.96. Found: C, $57.41 ; \mathrm{H}, 6.57 ; \mathrm{N}, 3.86$.

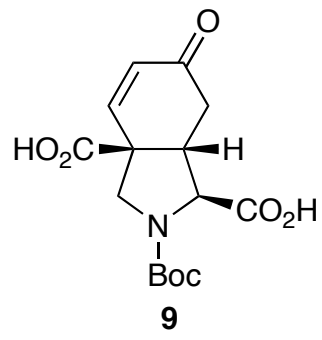

(1S)-2-(tert-Butoxycarbonyl)-6-oxo-2,3,3a,6,7,7a-hexahydro-1 $H$-isoindole-1,3a-

dicarboxylic Acid (9). A solution of enone diester 8 (3.10 g, $8.78 \mathrm{mmol})$ in THF (30 mL) was treated with $\mathrm{LiOH}(2 \mathrm{~N}, 20 \mathrm{~mL})$ and the reaction mixture was stirred for $1.5 \mathrm{~h}$, whereupon water and ether were added. The separated aqueous layer was treated with $2 \mathrm{~N}$ $\mathrm{HCl}$ to $\mathrm{pH} 2$ and then extracted with ether and AcOEt. These organic extracts were combined, washed with brine, dried over $\mathrm{Na}_{2} \mathrm{SO}_{4}$, and concentrated under reduced pressure to provide $2.80 \mathrm{~g}(98 \%)$ of enone diacid 9. Recrystallization of this material from hot hexaneAcOEt afforded with $82 \%$ recovery the enantiopure (ee $>99 \%$ ) enone diacid 9: mp 116-117 ${ }^{\circ} \mathrm{C}$ (dec); $[\alpha]^{20}{ }_{\mathrm{D}}-21.7$ (c 0.5, $\mathrm{CHCl}_{3}$ ); IR (film) 1737, 1719, 1683, 1675, 1650, 1242, 1162 $\mathrm{cm}^{-1} ;{ }^{1} \mathrm{H}$ NMR (300 MHz, CD $\mathrm{OD}, 2$ rotamers) $\delta 6.93$ (app.dd, $\left.J=1.8,10.2 \mathrm{~Hz}, 1 \mathrm{H}\right), 6.20$ (d, $J=10.2 \mathrm{~Hz}, 1 \mathrm{H}), 4.00-3.83(\mathrm{~m}, 3 \mathrm{H}), 3.30-3.24(\mathrm{~m}, 1 \mathrm{H}), 2.98$ and $2.96(2 \mathrm{~d}, J=17.7 \mathrm{~Hz}, 1 \mathrm{H})$, 2.71 and $2.66(2 \mathrm{dd}, J=2.3,17.7 \mathrm{~Hz}, 1 \mathrm{H}), 1.49$ and $1.43(2 \mathrm{~s}, 9 \mathrm{H}) ;{ }^{13} \mathrm{C} \mathrm{NMR}(75 \mathrm{MHz}$, $\left.\mathrm{CD}_{3} \mathrm{OD}\right) \delta 198.3,175.7,175.3,173.0,156.2,155.9,150.2,150.1,133.3,133.2,83.2,83.0$, 65.1, 64.7, 57.9, 57.4, 54.4, 53.7, 47.2, 46.5, 37.7, 37.6, 29.5, 29.3; MS (DCI, $\mathrm{NH}_{3} /$ isobutane) $m / z 325$ (100\%), 214, 180; HRMS (LTQ-Orbitrap, ESI) Calcd. for $\mathrm{C}_{15} \mathrm{H}_{19} \mathrm{NO}_{7} \mathrm{Na}$ : 348.1059. Found $348.1054\left(\mathrm{M}+\mathrm{Na}^{+}\right)$. 


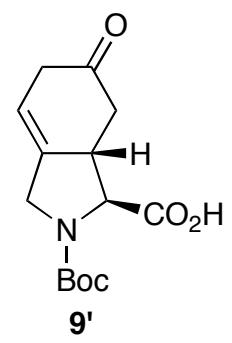

(1S)-2-(tert-Butoxycarbonyl)-6-oxo-2,3,5,6,7,7a-hexahydro-1H-isoindole-1-

carboxylic Acid (9'). To a mixture of enone diacid $9(0.932 \mathrm{~g}, 2.86 \mathrm{mmol})$ in toluene (10 $\mathrm{mL})$ was added dry pyridine $(1.20 \mathrm{~mL}, 14.8 \mathrm{mmol})$. The reaction mixture was refluxed for $2.5 \mathrm{~h}$ and then cooled to $0{ }^{\circ} \mathrm{C}$ and treated with $2 \mathrm{~N} \mathrm{HCl}$ to $\mathrm{pH} 2$. The mixture was extracted with ether, which was washed with brine, dried over $\mathrm{Na}_{2} \mathrm{SO}_{4}$, and concentrated under reduced pressure to give $0.782 \mathrm{~g}$ of crude enone acid 9'. An analytical sample was obtained from a comparable sample by chromatography on silica gel (80:20:0.5 AcOEt-pentane-AcOH): mp $136{ }^{\circ} \mathrm{C}$ (dec); $[\alpha]^{20}{ }_{\mathrm{D}}+53.4$ (c 0.5, $\mathrm{CHCl}_{3}$ ); IR (film) 3468, 1730, 1719, 1707, 1683, 1253, 1169, $1028 \mathrm{~cm}^{-1} ;{ }^{1} \mathrm{H}$ NMR (300 MHz, $\mathrm{CDCl}_{3}, 2$ rotamers) $\delta 9.24$ (br s, $\left.1 \mathrm{H}\right), 5.76$ (br s, $\left.1 \mathrm{H}\right)$, 4.23-3.98 (m, 3H), 3.20 (br s, 1H), 3.01-2.76 (m, 3H), 2.47-2.27 (m, 1H), 1.46 and $1.42(2 \mathrm{~s}$, $9 \mathrm{H}) ;{ }^{13} \mathrm{C} \mathrm{NMR}\left(75 \mathrm{MHz}, \mathrm{CDCl}_{3}, 2\right.$ rotamers) $\delta 207.1,176.7,174.8,153.5,137.1,136.4$, 116.5, 81.4, 65.4, 50.4, 49.9, 43.8, 42.8, 42.6, 38.4, 28.1; MS (ESI $\left.{ }^{+}\right) \mathrm{m} / z 304\left(\mathrm{M}+\mathrm{Na}^{+}\right.$, 100\%), 272, 248, 226. Anal. Calcd. for $\mathrm{C}_{14} \mathrm{H}_{19} \mathrm{NO}_{5}$ : C, 59.78; H, 6.81; N, 4.98. Found: C, $59.53 ; \mathrm{H}, 6.76 ; \mathrm{N}, 4.99$.

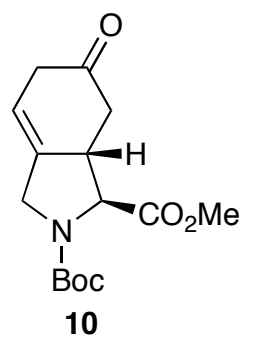

(1S)-2-tert-Butyl 1-Methyl 6-Oxo-5,6,7,7a-tetrahydro-1 $H$-isoindole-1,2(3H)dicarboxylate (10). A solution of crude enone acid $9^{\prime}(0.782 \mathrm{~g})$ in ether $(10 \mathrm{~mL})$ at $0{ }^{\circ} \mathrm{C}$ was treated with ethereal $\mathrm{CH}_{2} \mathrm{~N}_{2}$ (ca. $0.3 \mathrm{M}, 10 \mathrm{~mL}$ ). After $20 \mathrm{~min}$, the solvent was removed under reduced pressure and the crude product was purified by chromatography on silica gel (40:60 AcOEt-pentane) to give $0.700 \mathrm{~g}$ (83\%, 2 steps) of enone ester 10: $\mathrm{mp} 67-69{ }^{\circ} \mathrm{C} ;[\alpha]^{20}{ }_{\mathrm{D}}$ +57.0 (c 0.5, $\mathrm{CHCl}_{3}$ ); IR (film) 1750, 1740, 1719, 1709, 1685, 1160, 1022, $998 \mathrm{~cm}^{-1} ;{ }^{1} \mathrm{H}$ NMR (300 MHz, $\mathrm{CDCl}_{3}, 2$ rotamers) $\delta 5.75$ (br s, $\left.1 \mathrm{H}\right), 4.22-4.12(\mathrm{~m}, 2 \mathrm{H}), 4.05-3.95(\mathrm{~m}, 1 \mathrm{H})$, $3.75(\mathrm{~s}, 3 \mathrm{H}), 3.14-2.75(\mathrm{~m}, 4 \mathrm{H}), 2.43$ and $2.38(2 \mathrm{~d}, J=12.0,12.3 \mathrm{~Hz}, 1 \mathrm{H}), 1.45$ and $1.41(2 \mathrm{~s}$, 
$9 \mathrm{H}) ;{ }^{13} \mathrm{C}$ NMR $\left(75 \mathrm{MHz}, \mathrm{CDCl}_{3}, 2\right.$ rotamers) $\delta$ 206.7, 171.9, 171.6, 153.0, 152.9, 136.5,

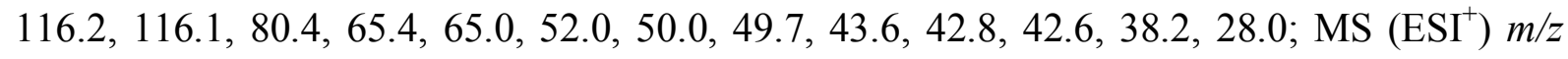
$318\left(\mathrm{M}+\mathrm{Na}^{+}, 100 \%\right)$. Anal. Calcd. for $\mathrm{C}_{15} \mathrm{H}_{21} \mathrm{NO}_{5}$ : C, 61.00; H, 7.17; N, 4.74. Found: C, $60.70 ; \mathrm{H}, 7.18 ; \mathrm{N}, 4.59$.

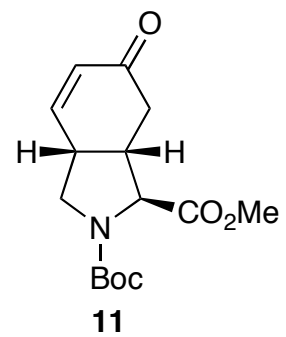

(1S,3aR,7aS)-2-tert-Butyl 1-Methyl 6-Oxo-3,3a,7,7a-tetrahydro-1H-isoindole1,2(6H)-dicarboxylate (11). A solution of enone ester 10 (0.700 g, $2.37 \mathrm{mmol})$ and DBU $(0.050 \mathrm{~mL}, 0.33 \mathrm{mmol})$ in $\mathrm{CH}_{2} \mathrm{Cl}_{2}(5.0 \mathrm{~mL})$ at $20{ }^{\circ} \mathrm{C}$ under argon was stirred for $4 \mathrm{~h}$, whereupon at $0{ }^{\circ} \mathrm{C} 2 \mathrm{~N} \mathrm{HCl}$ was added to $\mathrm{pH}$. The mixture was extracted with $\mathrm{CH}_{2} \mathrm{Cl}_{2}$, which was washed with brine, dried over $\mathrm{Na}_{2} \mathrm{SO}_{4}$, and concentrated under reduced pressure. Purification of the residue by chromatography on silica gel (60:40 AcOEt-pentane) afforded $0.607 \mathrm{~g}(87 \%)$ of enone ester 11: $[\alpha]^{20}{ }_{\mathrm{D}}-116.1\left(c 0.5, \mathrm{CHCl}_{3}\right)$; IR (film) 1755, 1686, 1675, 1122, 1025, $859 \mathrm{~cm}^{-1} ;{ }^{1} \mathrm{H}$ NMR (300 MHz, $\mathrm{CDCl}_{3}, 2$ rotamers) $\delta 6.77$ and $6.74(2 \mathrm{dd}, J=4.3$, $10.2 \mathrm{~Hz}, 1 \mathrm{H}), 6.13-6.07(\mathrm{~m}, 1 \mathrm{H}), 4.09$ and $3.96(2 \mathrm{~d}, J=5.1,6.6 \mathrm{~Hz}, 1 \mathrm{H}), 3.90-3.80(\mathrm{~m}, 1 \mathrm{H})$, $3.75(\mathrm{~s}, 3 \mathrm{H}), 3.66,3.33$ and 3.54-3.47 (2 dd $+\mathrm{m}, J=3.8,10.7 \mathrm{~Hz}, 1 \mathrm{H}), 3.20-3.08(\mathrm{~m}, 1 \mathrm{H})$, 2.97-2.85 (m, 1H), $2.65(\mathrm{~d}, J=5.3 \mathrm{~Hz}, 2 \mathrm{H}), 1.46$ and $1.39(2 \mathrm{~s}, 9 \mathrm{H}) ;{ }^{13} \mathrm{C} \mathrm{NMR}(75 \mathrm{MHz}$, $\mathrm{CDCl}_{3}, 2$ rotamers) $\delta 195.2,171.8,171.4,153.2,152.6,148.5,147.8,130.0,129.9,79.6,62.2$, 62.1, 51.6, 51.5, 50.7, 42.0, 41.2, 37.1, 37.0, 36.8, 36.6, 27.6, 27.5; MS (ESI $\left.{ }^{+}\right) \mathrm{m} / z 302(\mathrm{M}+$ $\mathrm{Li}^{+}, 100 \%$ ), 246. Anal. Calcd. for $\mathrm{C}_{15} \mathrm{H}_{21} \mathrm{NO}_{5}$ : C, 61.00; H, 7.17; N, 4.74. Found: C, 60.76; H, 7.29; N, 4.59.

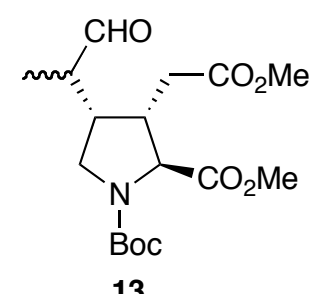

(2R,3S,4S)-1-tert-Butyl 2-Methyl 3-(2-Methoxy-2-oxoethyl)-4-((R)-1-oxopropan-2yl)pyrrolidine-1,2-dicarboxylate (13). An argon-flushed flask was charged with $\mathrm{CuCN}$ $(0.495 \mathrm{~g}, 5.53 \mathrm{mmol})$ and THF $(10 \mathrm{~mL})$ was added. The flask was cooled to $-78{ }^{\circ} \mathrm{C}$ and 
MeLi (1.6 M solution in ether, $6.9 \mathrm{~mL}, 11.0 \mathrm{mmol}$ ) was added slowly. Stirring was continued for $30 \mathrm{~min}$ at $-78{ }^{\circ} \mathrm{C}$ and then a mixture of enone ester $11(0.544 \mathrm{~g}, 1.84 \mathrm{mmol})$ and TMSCl $(1.42 \mathrm{~mL}, 11.11 \mathrm{mmol})$ in THF $(6 \mathrm{~mL})$ was added. After $45 \mathrm{~min}$ at $-78{ }^{\circ} \mathrm{C}$, the reaction mixture was quenched by the addition of an aqueous solution of $\mathrm{NH}_{4} \mathrm{Cl}-\mathrm{NH}_{4} \mathrm{OH}$. The mixture was extracted with ether, which was washed with brine and dried over $\mathrm{Na}_{2} \mathrm{SO}_{4}$. The solvent was removed under reduced pressure to give the crude enol ether $(0.683 \mathrm{~g})$, which was used directly for the next reaction. Enol ether 12: ${ }^{1} \mathrm{H}$ NMR $\left(300 \mathrm{MHz}, \mathrm{CDCl}_{3}, 2\right.$ rotamers) $\delta 4.75-4.70(\mathrm{~m}, 1 \mathrm{H}), 4.02$ and $3.89(2 \mathrm{~d}, J=5.8,7.6 \mathrm{~Hz}, 1 \mathrm{H}), 3.74$ and $3.73(2 \mathrm{~s}$, $3 \mathrm{H}), 3.85-3.52(\mathrm{~m}, 1 \mathrm{H}), 3.44-3.37$ and 3.27-3.22 (2 m, 1H), 2.58 and $2.48(2 \mathrm{~m}, 1 \mathrm{H}), 2.32-$ $2.21(\mathrm{~m}, 1 \mathrm{H}), 2.16-1.80(\mathrm{~m}, 3 \mathrm{H}), 1.45$ and $1.39(2 \mathrm{~s}, 9 \mathrm{H}), 1.01(\mathrm{~d}, J=6.6 \mathrm{~Hz}, 3 \mathrm{H}), 0.19$ and $0.18(2 \mathrm{~s}, 9 \mathrm{H})$.

A stream of $\mathrm{O}_{3}$ in $\mathrm{O}_{2}$ was bubbled through a solution of $0.675 \mathrm{~g}$ of the above crude enol ether in $\mathrm{CH}_{2} \mathrm{Cl}_{2}-\mathrm{MeOH}(3: 1,10 \mathrm{~mL})$ at $-116{ }^{\circ} \mathrm{C}$. When the blue color persisted (ca. 10 min), dimethyl sulfide $(1.5 \mathrm{~mL})$ was added and reaction mixture was allowed to warm to 20 ${ }^{\circ} \mathrm{C}$ and was stirrred for $2 \mathrm{~h}$. The solvents were then removed under reduced pressure and the residue was taken up in ether, which was washed with brine and dried over $\mathrm{Na}_{2} \mathrm{SO}_{4}$. The solvent was removed under reduced pressure to give the the crude aldehyde acid (0.712 $\mathrm{g})$, which was used directly for the next step.

A solution of the above crude aldehyde acid $(0.712 \mathrm{~g})$ in ether $(10 \mathrm{~mL})$ was cooled to $0{ }^{\circ} \mathrm{C}$ and treated with ethereal $\mathrm{CH}_{2} \mathrm{~N}_{2}$ (ca. $0.3 \mathrm{M}, 8.3 \mathrm{~mL}$ ). After $15 \mathrm{~min}$, the solvent was removed under reduced pressure and the crude product was purified by chromatography on silica gel (40:60 AcOEt-pentane) to afford $0.453 \mathrm{~g}$ (70\%, 3 steps) of unstable aldehyde ester 13: IR (film) 1740, 1697, 1206, 1167, 1002, $898 \mathrm{~cm}^{-1} ;{ }^{1} \mathrm{H}$ NMR (300 MHz, $\mathrm{CDCl}_{3}, 2$ rotamers) $\delta 9.56(\mathrm{br} \mathrm{s}, 1 \mathrm{H}), 4.22-4.12(\mathrm{~m}, 1 \mathrm{H}), 3.87-3.63(\mathrm{~m}, 2 \mathrm{H}), 3.74(\mathrm{~s}, 3 \mathrm{H}), 3.69(\mathrm{~s}, 3 \mathrm{H})$, 3.37-3.30 and 3.16-3.04 (2 m, 1H), 2.97-2.87 and 2.72-2.58 (2 m, 1H), 2.50-2.18 (m, 3H), 1.45 and $1.39(2 \mathrm{~s}, 9 \mathrm{H}), 1.13(\mathrm{~d}, J=7.1 \mathrm{~Hz}, 3 \mathrm{H})$. 


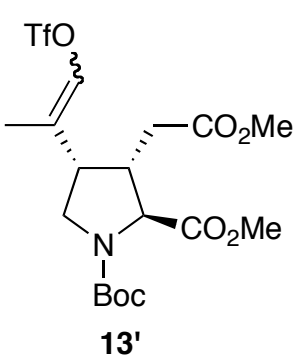

$(2 R, 3 S, 4 S)-1-t e r t-B u t y l$
2-Methyl
3-(2-Methoxy-2-oxoethyl)-4-(1-

(trifluoromethylsulfonyloxy)prop-1-en-2-yl)pyrrolidine-1,2-dicarboxylate $\left(1^{\prime}\right)$. To a stirred solution of KHMDS $(0.065 \mathrm{~g}, 0.33 \mathrm{mmol})$ in THF $(3 \mathrm{~mL})$ at $-78{ }^{\circ} \mathrm{C}$ was added aldehyde ester $13(0.053 \mathrm{~g}, 0.15 \mathrm{mmol})$ in THF $(2 \mathrm{~mL})$. After $15 \mathrm{~min}$, the reaction mixture was treated with a solution of 2-[N,N-bis-(trifluoromethylsulfonyl)amino]-5-chloropyridine $(0.128 \mathrm{~g}, 0.33 \mathrm{mmol})$ in THF $(3 \mathrm{~mL})$, stirred for $1.5 \mathrm{~h}$, and then allowed to warm to $0{ }^{\circ} \mathrm{C}$. An aqueous solution of $\mathrm{NH}_{4} \mathrm{Cl}-\mathrm{NH}_{4} \mathrm{OH}$ was added and the mixture was extracted with ether, which was washed with brine and dried over $\mathrm{Na}_{2} \mathrm{SO}_{4}$. The solvent was removed under reduced pressure to yield the crude product, which was purified by chromatography on silica gel (15:85 AcOEt-pentane) to afford the $0.046 \mathrm{~g} \mathrm{(63 \% )} \mathrm{of} \mathrm{enol} \mathrm{triflate} \mathbf{1 3}^{\prime}$ and $0.005 \mathrm{~g}$ of the starting aldehyde ester 13. Enol triflate 13': $[\alpha]^{20}{ }_{\mathrm{D}}-37.8$ (c 1.1, $\mathrm{CHCl}_{3}$ ); IR (film) 3100 , 1751, 1730, 1704, 1686, 1140, 1057, $1018 \mathrm{~cm}^{-1} ;{ }^{1} \mathrm{H} \mathrm{NMR}\left(300 \mathrm{MHz}, \mathrm{CDCl}_{3}, 2\right.$ rotamers) $\delta$ 6.49, $6.36(2 \mathrm{~s}, 1 \mathrm{H}), 4.00-3.90(\mathrm{~m}, 1 \mathrm{H}), 3.76-3.55(\mathrm{~m}, 9 \mathrm{H}), 3.13-2.87(\mathrm{~m}, 1 \mathrm{H}), 2.58-2.27(\mathrm{~m}$, $2 \mathrm{H}), 1.71$ and $1.61(2 \mathrm{~d}, J=1.5 \mathrm{~Hz}, 3 \mathrm{H}), 1.45$ and $1.39(2 \mathrm{~s}, 9 \mathrm{H}) ;{ }^{13} \mathrm{C} \mathrm{NMR}\left(75 \mathrm{MHz}, \mathrm{CDCl}_{3}\right.$, 2 rotamers) $\delta 172.2,172.0,171.6,171.1,153.6,153.0,132.6,132.5,125.6,125.5$, (124.8, 120.6, 116.3, 112.1) $\mathrm{CF}_{3}, 80.76,80.71,63.5,63.4,63.14,63.0,52.42,52.37,52.26,52.20$, 51.92, 51.89, 48.7, 48.3, 43.0, 42.9, 42.13, 42.10, 38.7, 37.8, 33.2, 33.1, 32.9, 32.8, 28.3 28.1; MS (ESI $\left.{ }^{+}\right) \mathrm{m} / z 496\left(\mathrm{M}+\mathrm{Li}^{+}, 100 \%\right), 344$; HRMS (LTQ-Orbitrap, ESI) Calcd. for $\mathrm{C}_{18} \mathrm{H}_{26} \mathrm{~F}_{3} \mathrm{NO}_{9} \mathrm{SNa}:$ 512.1178. Found 512.1173 $\left(\mathrm{M}+\mathrm{Na}^{+}\right)$.

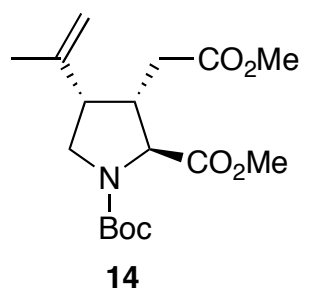

(2S,3S,4S)-1-tert-butyl 2-methyl 3-(2-methoxy-2-oxoethyl)-4-(prop-1-en-2yl)pyrrolidine-1,2-dicarboxylate (14). A mixture of enol triflate 13' (0.105 g, $0.21 \mathrm{mmol})$, $\mathrm{LiCl}(0.027 \mathrm{~g}, 0.64 \mathrm{mmol}),\left(\mathrm{PPh}_{3}\right)_{4} \mathrm{Pd}(0.050 \mathrm{~g}, 0.04 \mathrm{mmol})$, and triethylsilane $(0.075 \mathrm{~g}, 0.64$ mmol) in DMF (3.0 mL) was stirred at $55^{\circ} \mathrm{C}$ for $2 \mathrm{~h}$, whereupon it was allowed to cool to 20 
${ }^{\circ} \mathrm{C}$ and ether and water were added. The mixture was extracted with ether, which was washed with brine, dried over $\mathrm{Na}_{2} \mathrm{SO}_{4}$, and concentrated under reduced pressure. The residue was purified by chromatography on silica gel (15:85 AcOEt-pentane) to give $0.070 \mathrm{~g}(96 \%)$ of olefin 14: $[\alpha]^{20}-20.0$ (c 0.7, $\mathrm{CHCl}_{3}$ ); IR (film) 3085, 1737, 1701, 1206, 1169, 1130, 1007, $898 \mathrm{~cm}^{-1} ;{ }^{1} \mathrm{H}$ NMR $\left(300 \mathrm{MHz}, \mathrm{CDCl}_{3}, 2\right.$ rotamers) $\delta 4.91$ and $4.69(2 \mathrm{~s}, 2 \mathrm{H}), 4.16$ and $4.06(2$ $\mathrm{d}, J=3.3,3.8 \mathrm{~Hz}, 1 \mathrm{H}), 3.79-3.62(\mathrm{~m}, 7 \mathrm{H}), 3.52-3.38(\mathrm{~m}, 1 \mathrm{H}), 3.07-2.97$ and 2.89-2.79 (2 m, $2 \mathrm{H}), 2.40-2.21(\mathrm{~m}, 2 \mathrm{H}), 1.69(\mathrm{~s}, 3 \mathrm{H}), 1.46$ and $1.40(2 \mathrm{~s}, 9 \mathrm{H}) ;{ }^{13} \mathrm{C} \mathrm{NMR}\left(75 \mathrm{MHz}, \mathrm{CDCl}_{3}, 2\right.$ rotamers) $\delta 172.6,172.4,172.3,172.2,153.7,153.6,141.3,141.2,113.3,113.180 .2,63.9$, 63.6, 52.2, 52.1, 51.7, 47.8, 47.5, 45.9, 45.2, 41.8, 40.9, 32.9, 28.3 28.1, 22.2, 22.1; $\mathrm{MS}_{\left(\mathrm{ESI}^{+}\right)}$ $m / z 348\left(\mathrm{M}+\mathrm{Li}^{+}, 100 \%\right), 303,261$; HRMS (LTQ-Orbitrap, ESI) Calcd. for $\mathrm{C}_{17} \mathrm{H}_{27} \mathrm{NO}_{6} \mathrm{Na}$ : 364.1736. Found $364.1731\left(\mathrm{M}+\mathrm{Na}^{+}\right)$.

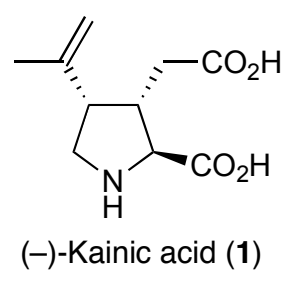

(2S,3S,4S)-3-(Carboxymethyl)-4-(prop-1-en-2-yl)pyrrolidine-2-carboxylic Acid (Kainic Acid) (1). A solution of olefin $14(0.0360 \mathrm{~g}, 0.105 \mathrm{mmol})$ in THF $(1.5 \mathrm{~mL})$ at $0{ }^{\circ} \mathrm{C}$ was treated with $2 \mathrm{~N} \mathrm{LiOH}(15 \mathrm{~mL})$ and then stirred for $10 \mathrm{~h}$ at $20^{\circ} \mathrm{C}$. The reaction mixture was acidified with $2 \mathrm{~N} \mathrm{HCl}$ to $\mathrm{pH} 3$ and then extracted with ethyl acetate, which was dried over $\mathrm{Na}_{2} \mathrm{SO}_{4}$ and concentrated. Dichloromethane $(2 \mathrm{~mL})$ and TFA $(0.106 \mathrm{~mL}, 1.43 \mathrm{mmol})$ were added to the residue, and the resulting reaction mixture was stirred for $10 \mathrm{~h}$. After removal of the solvent, the crude product was purified on Dowex-50 (WX8-200, $\mathrm{H}^{+}$form), eluting with $\mathrm{NH}_{4} \mathrm{OH}(0.1-0.5 \mathrm{~N})$, to afford $0.0206 \mathrm{~g}$ of slightly impure kainic acid. Recrystallization of this material from $\mathrm{MeOH}-\mathrm{H}_{2} \mathrm{O}$ provided the analytical sample $(0.0168 \mathrm{~g}$, 75\%): $\mathrm{mp} 241-243{ }^{\circ} \mathrm{C} ;[\alpha]^{20}{ }_{\mathrm{D}}-14.3\left(c 0.16, \mathrm{H}_{2} \mathrm{O}\right) ;{ }^{1} \mathrm{H}$ NMR $\left(300 \mathrm{MHz}, \mathrm{D}_{2} \mathrm{O}\right) \delta 5.11(\mathrm{~s}, 1 \mathrm{H})$, $4.82(\mathrm{~s}, 1 \mathrm{H}), 4.15(\mathrm{~d}, J=3.1 \mathrm{~Hz}, 1 \mathrm{H}), 3.70(\mathrm{dd}, J=11.7,7.4 \mathrm{~Hz}, 1 \mathrm{H}) 3.50(\mathrm{dd}, J=11.7,10.5$ $\mathrm{Hz}, 1 \mathrm{H}), 3.18-3.03$ (m, 2H), 2.45 (dd, $J=15.6,6.4 \mathrm{~Hz}, 1 \mathrm{H}), 2.34$ (dd, $J=15.68 .2 \mathrm{~Hz}, 1 \mathrm{H})$, $1.83(\mathrm{~s}, 3 \mathrm{H}) ;{ }^{13} \mathrm{C}$ NMR $\left(75 \mathrm{MHz}, \mathrm{CDCl}_{3}\right) \delta 179.8,174.0,140.6,113.3,66.2,46.7,46.2,42.1$, 36.2, 22.5. This material was spectroscopically and chromatographically indistinguishable from an authentic sample of the natural product. 


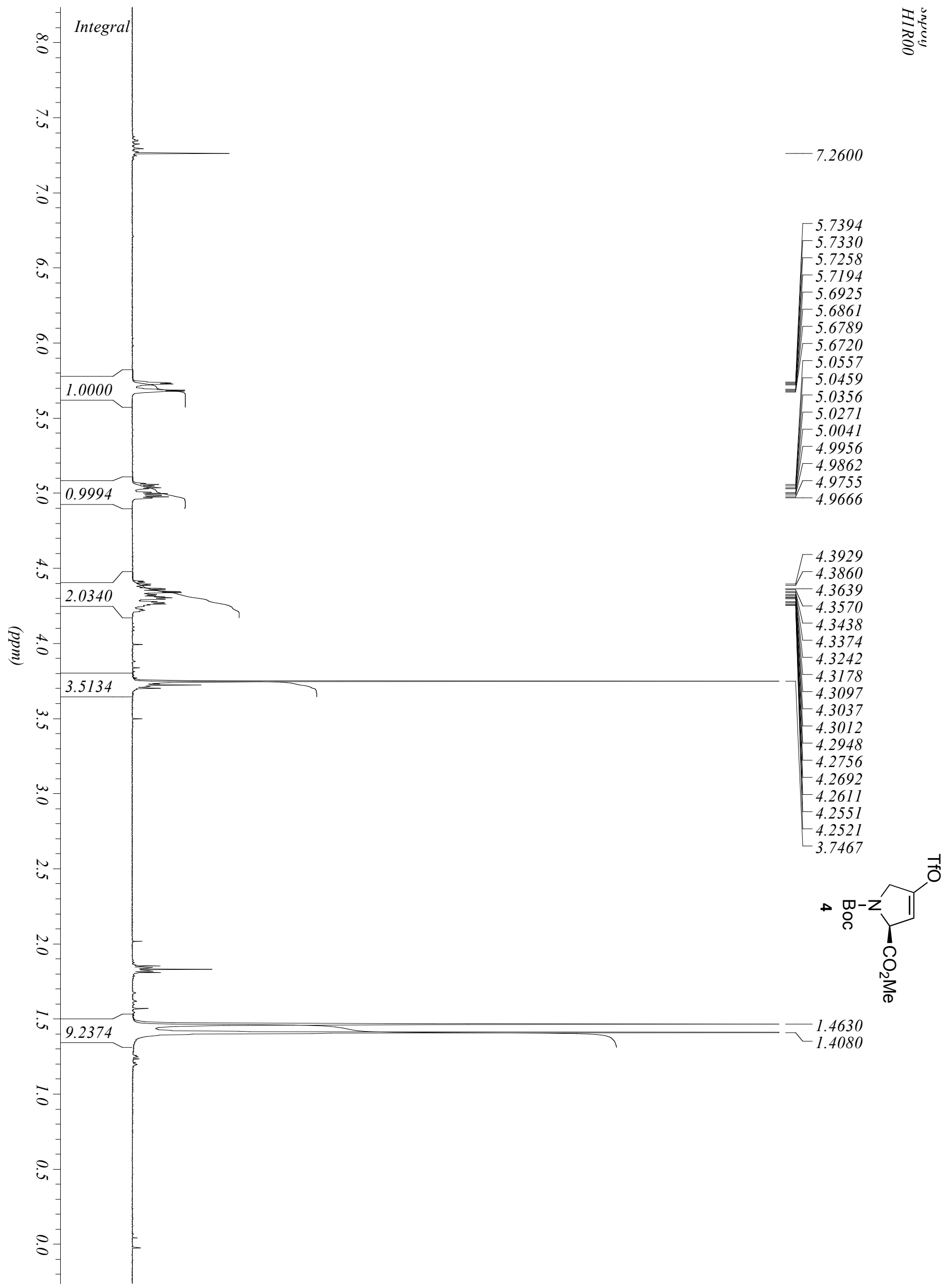




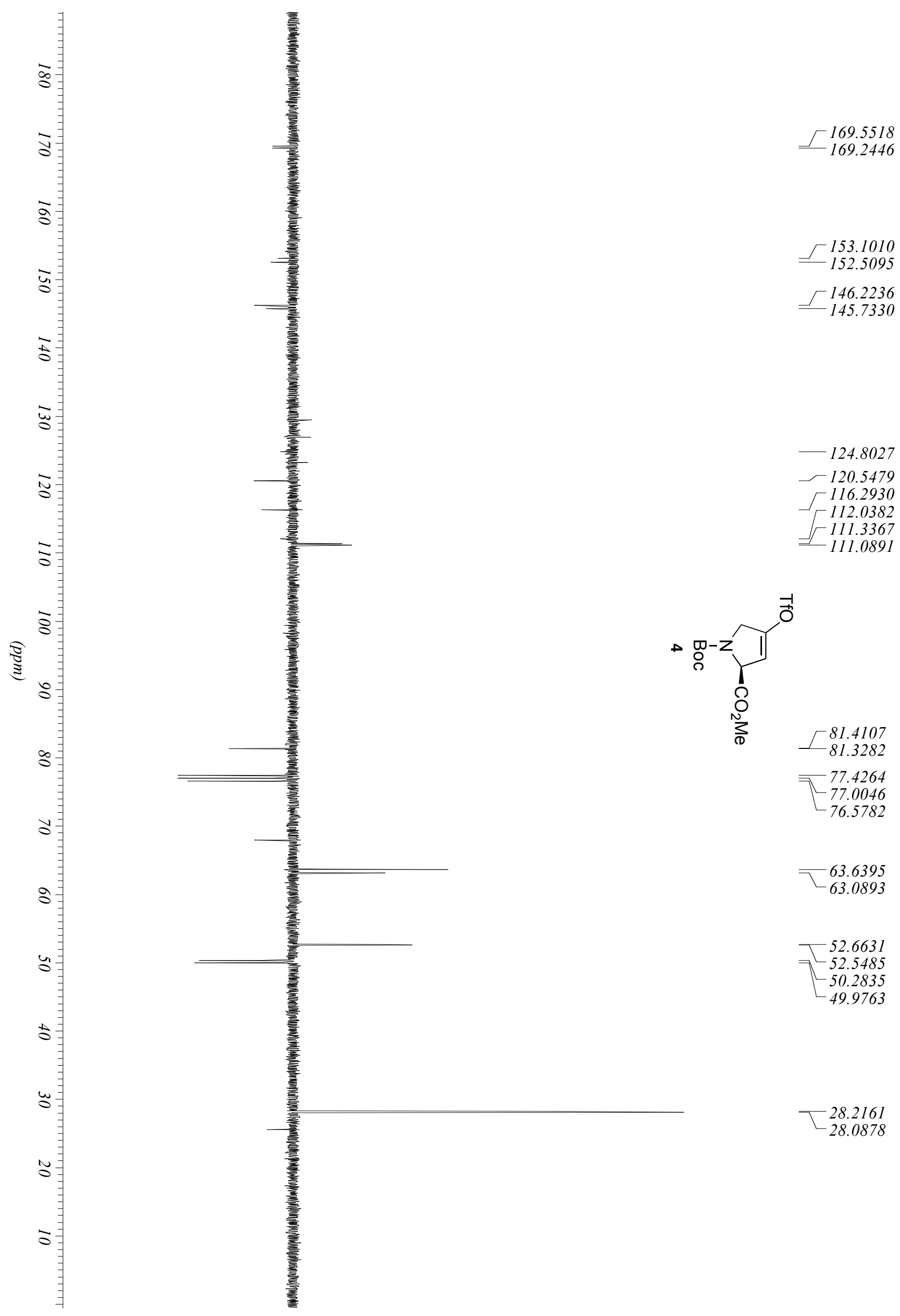




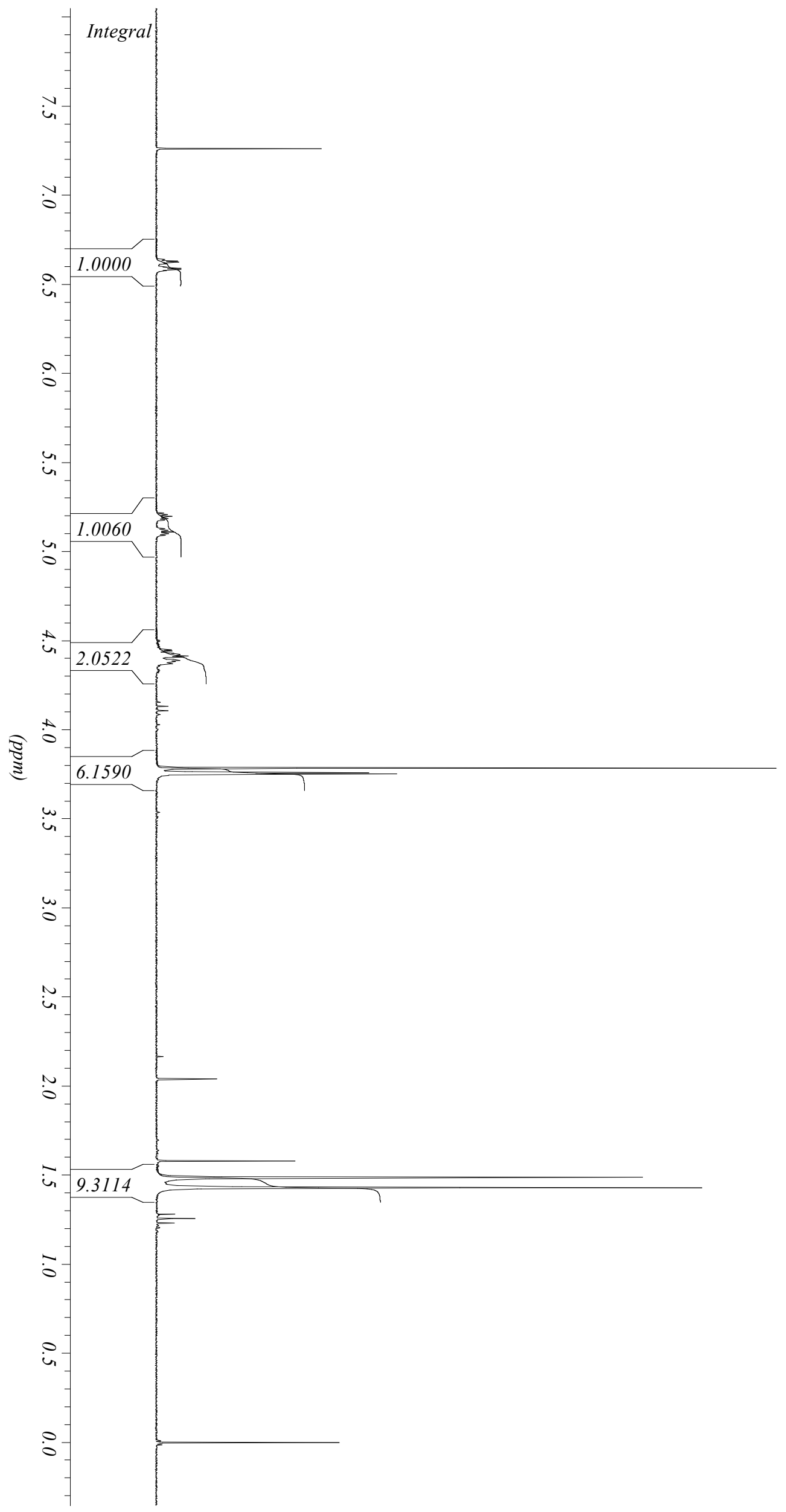

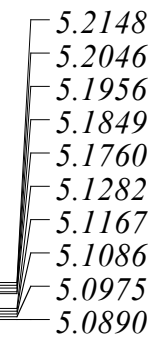

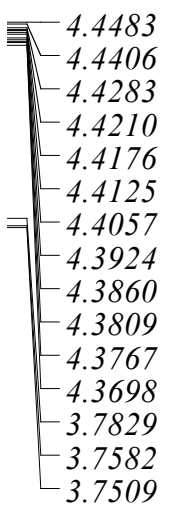

1.5786

$\ulcorner 1.4856$

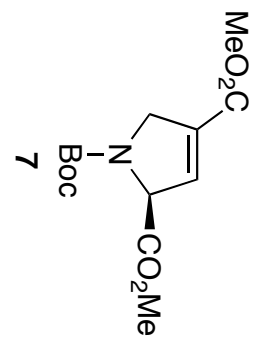




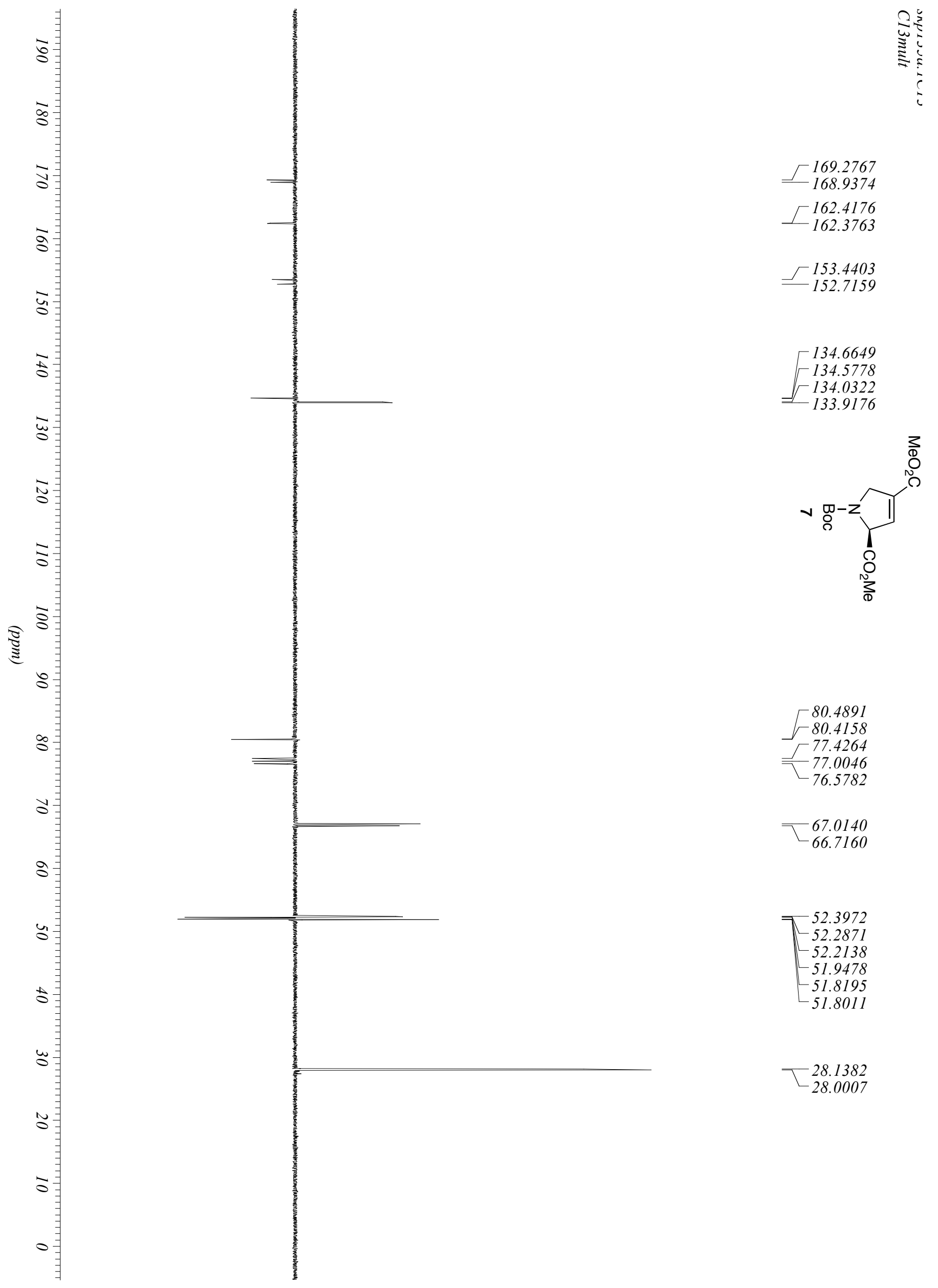




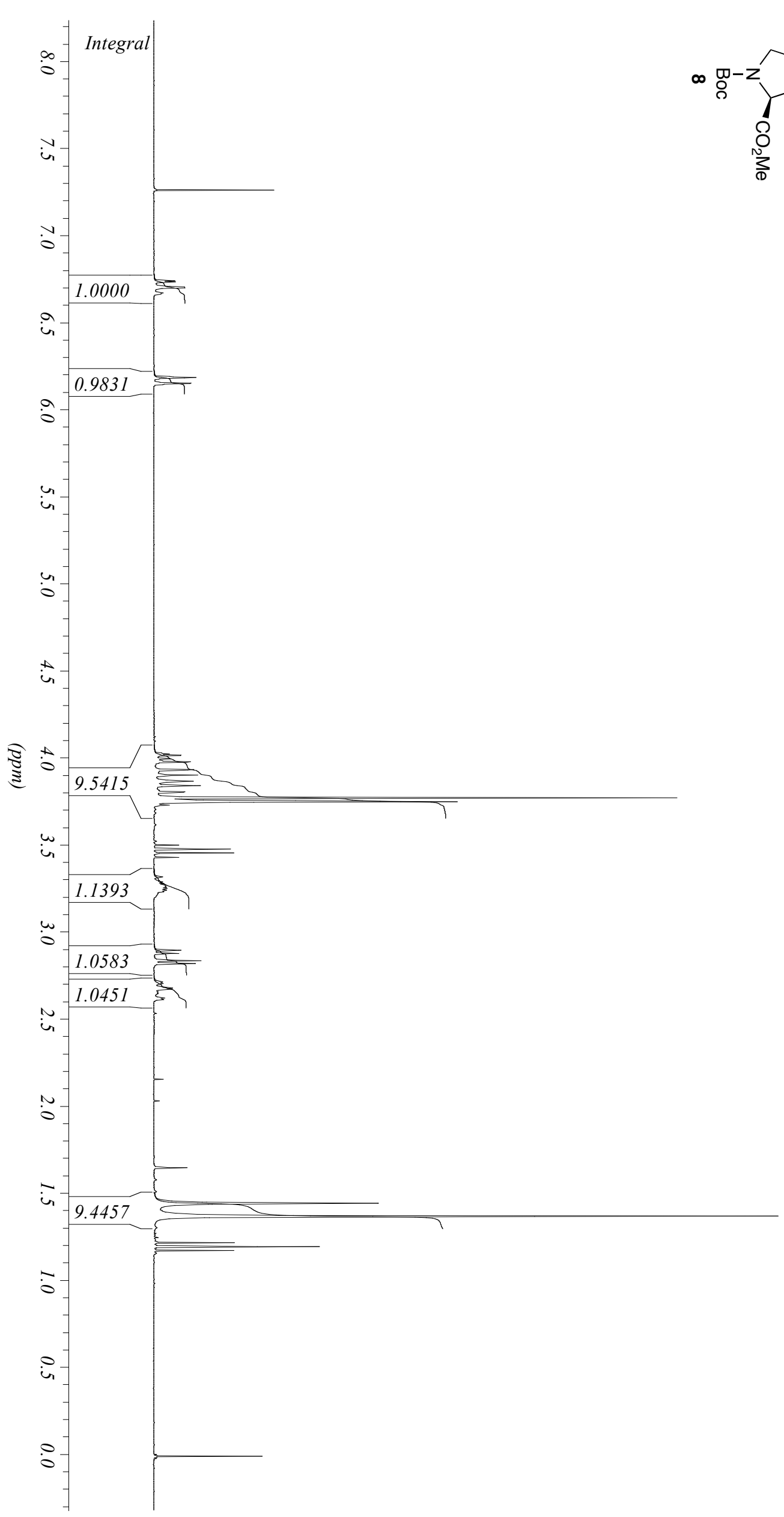

$-3.7536$

$-3.7472$

$-3.7285$

$-3.4994$

皮 -3.4760

$-3.4525$

$=-3.4290$

-3.3143

3.2862

$-3.2776$

$-3.2691$

$-3.2627$

$-3.2559$

$-3.2516$

$-3.2478$

$-3.2397$

$-3.2311$

2.8933

$-2.8759$

$-2.8345$

$-2.8170$

$-2.7116$

$-2.7027$

$-2.6784$

2.6703

$-2.6195$

2.6114

$-2.1542$

$-1.4415$

$-1.3664$

$-1.2150$

$-1.1920$

$-1.1685$ 


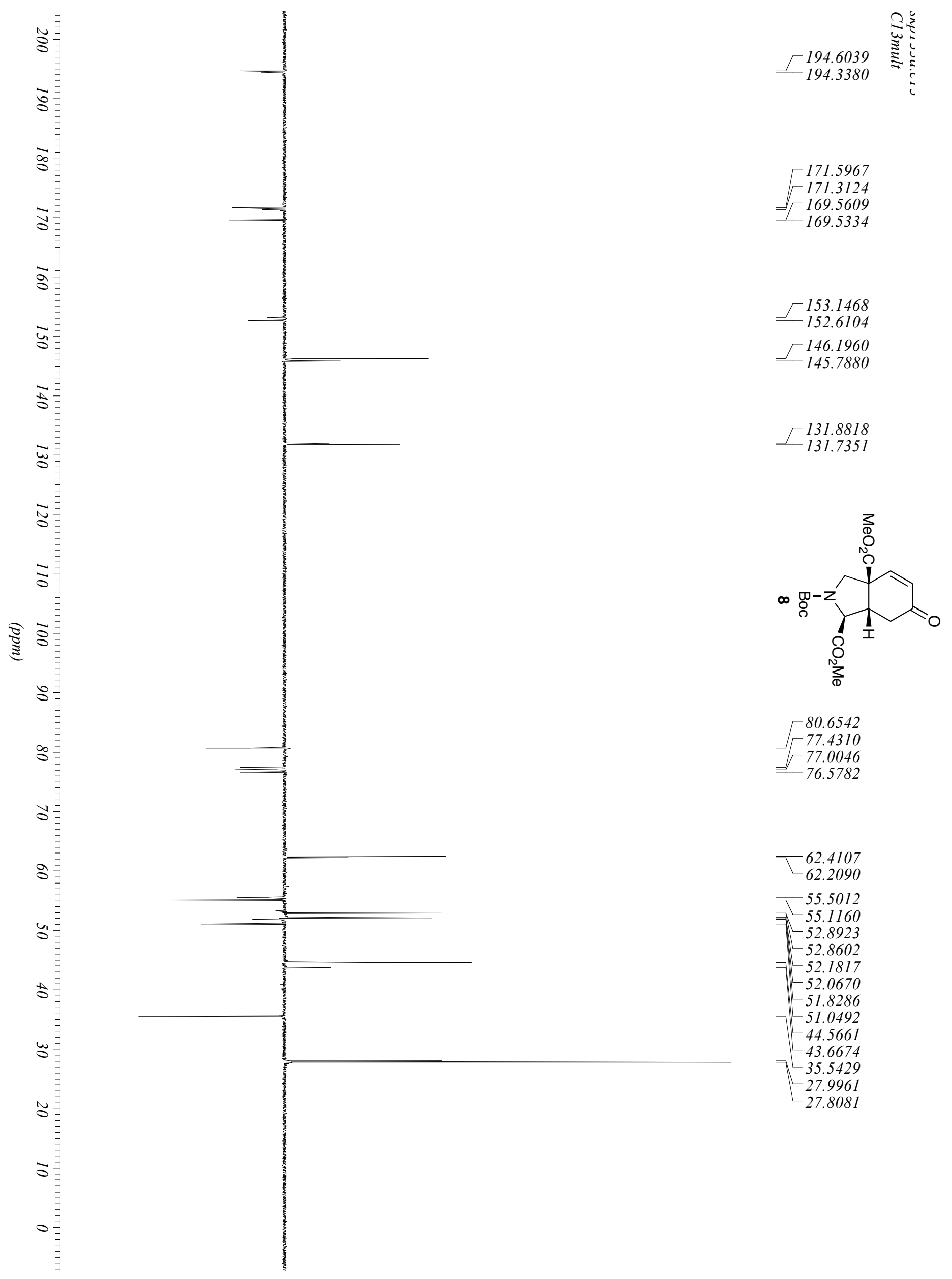




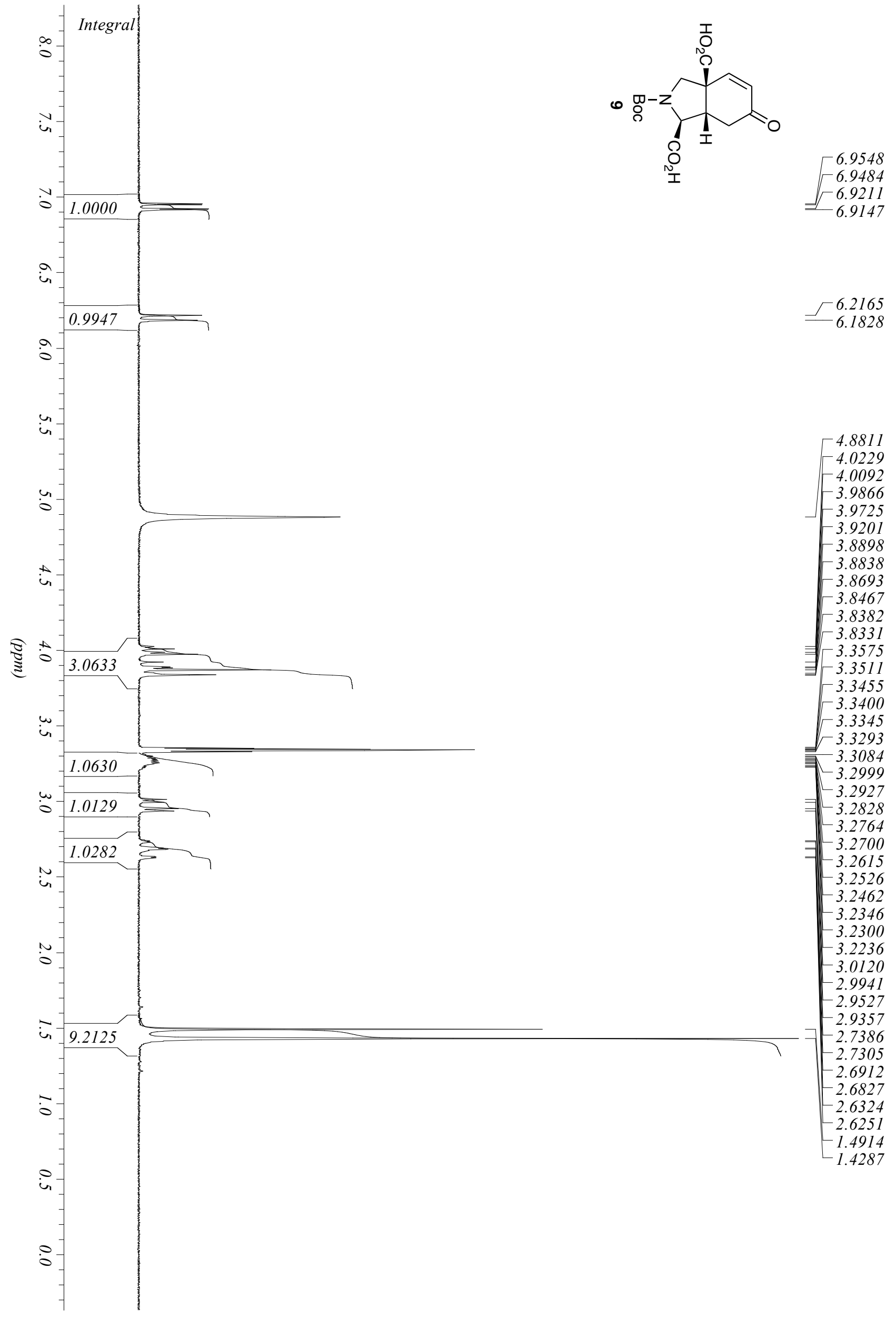




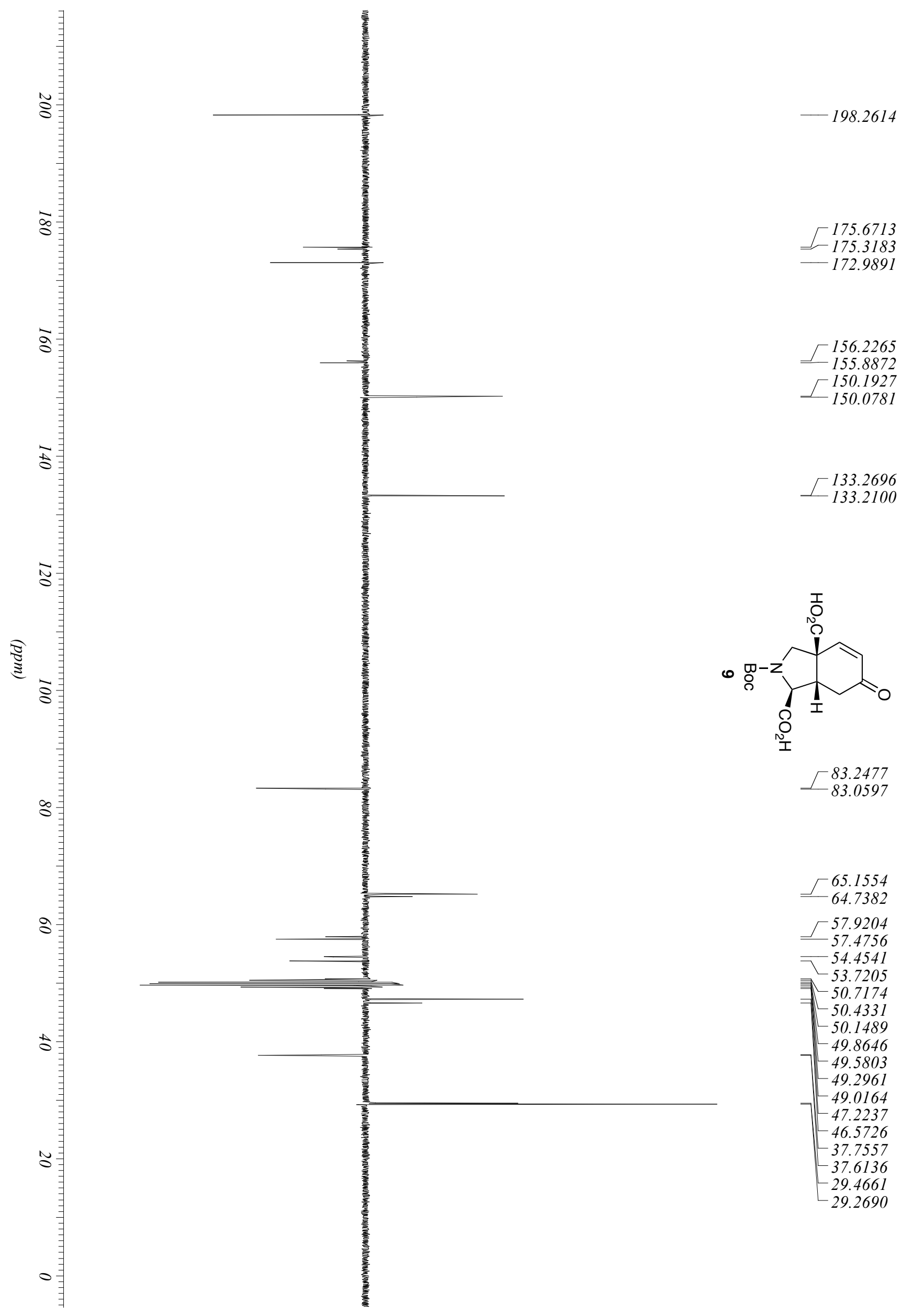



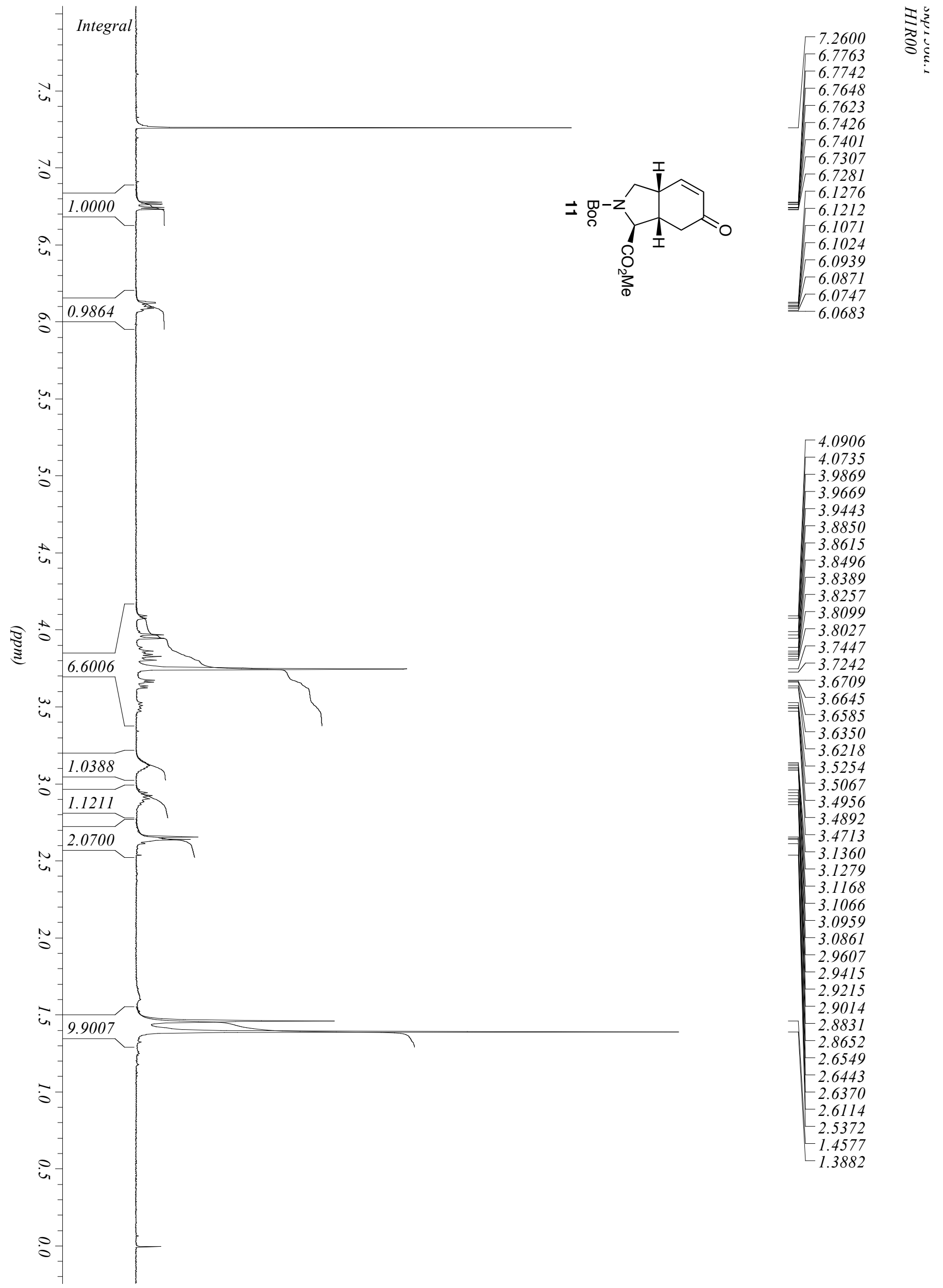


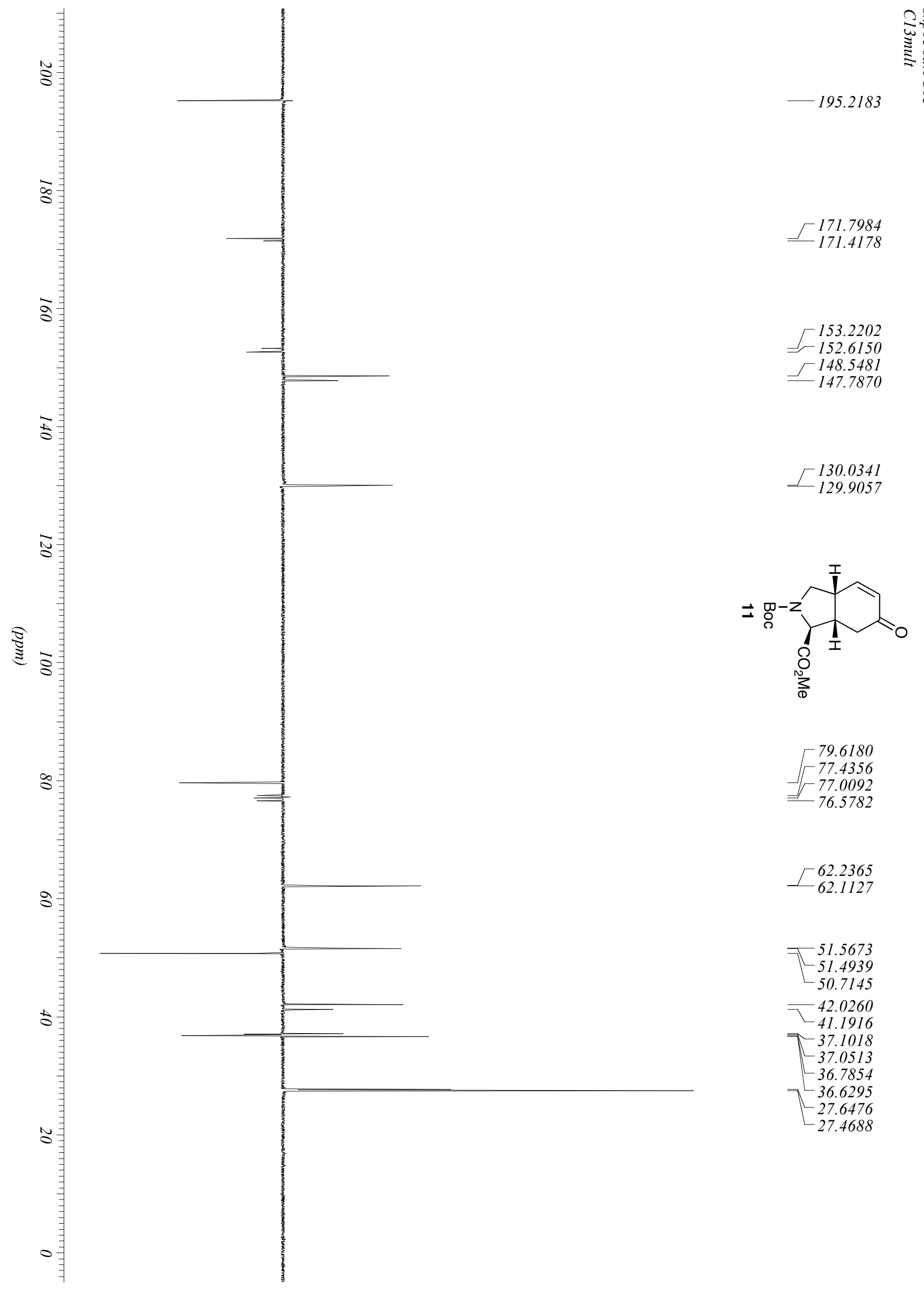




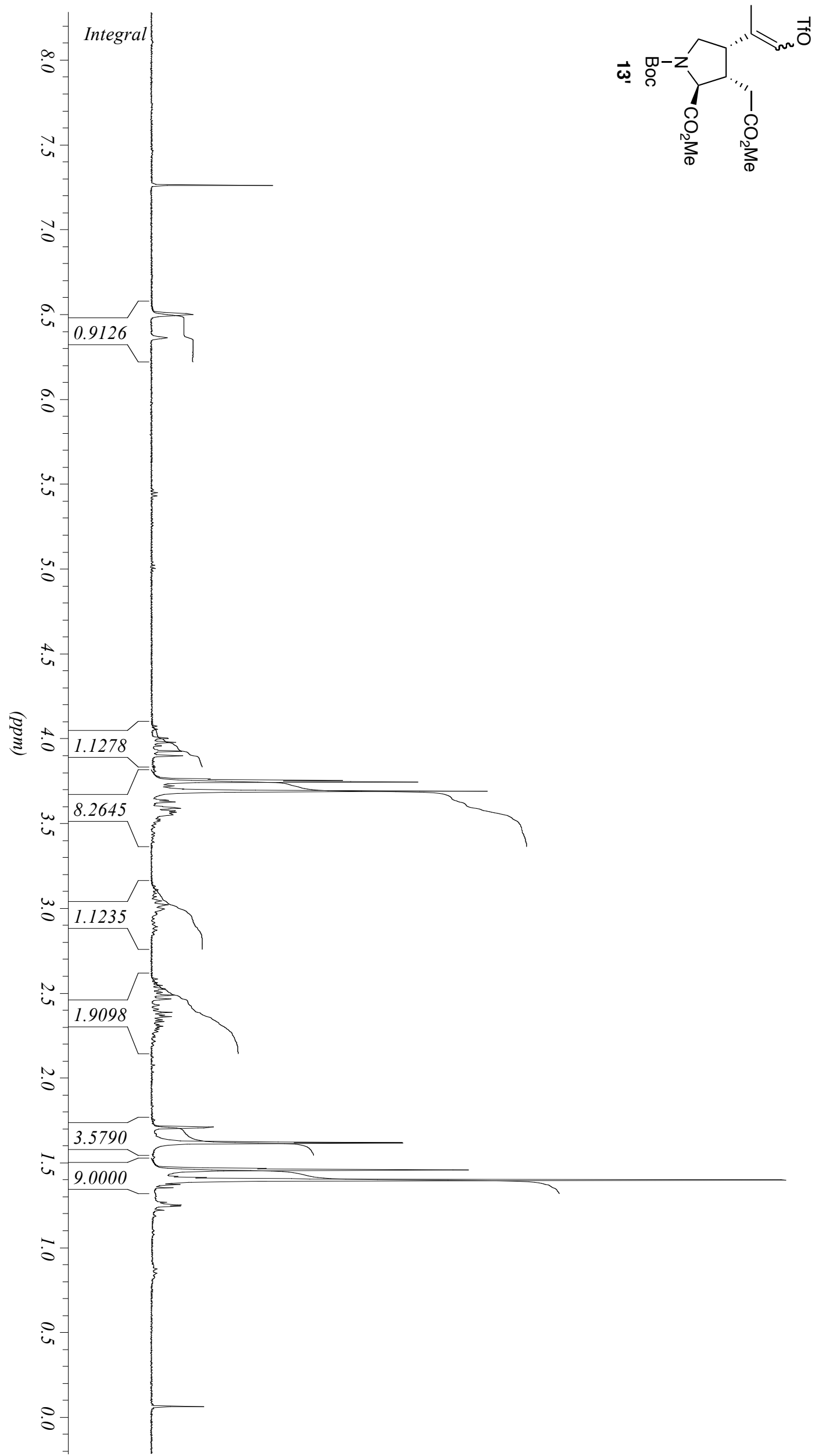



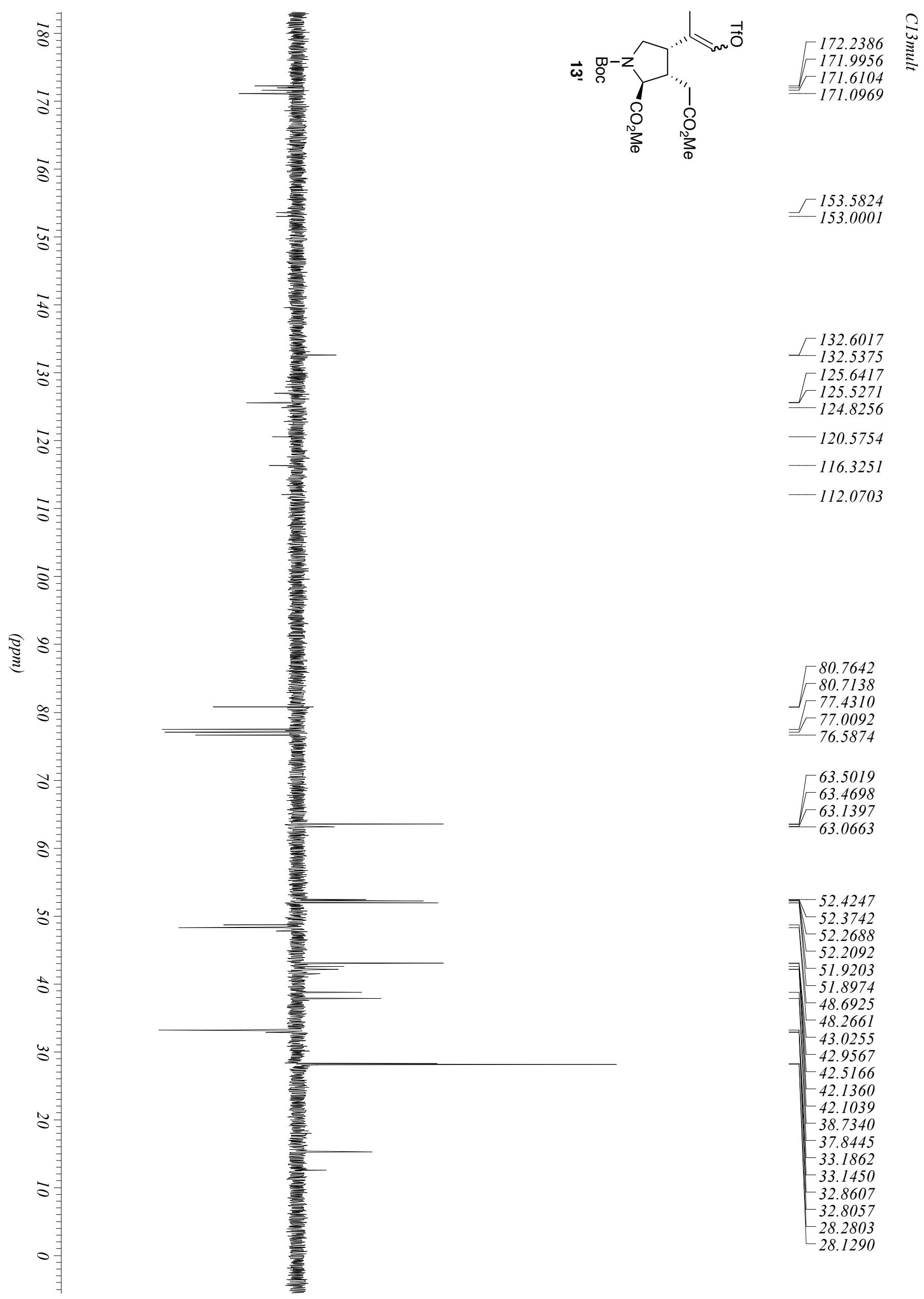


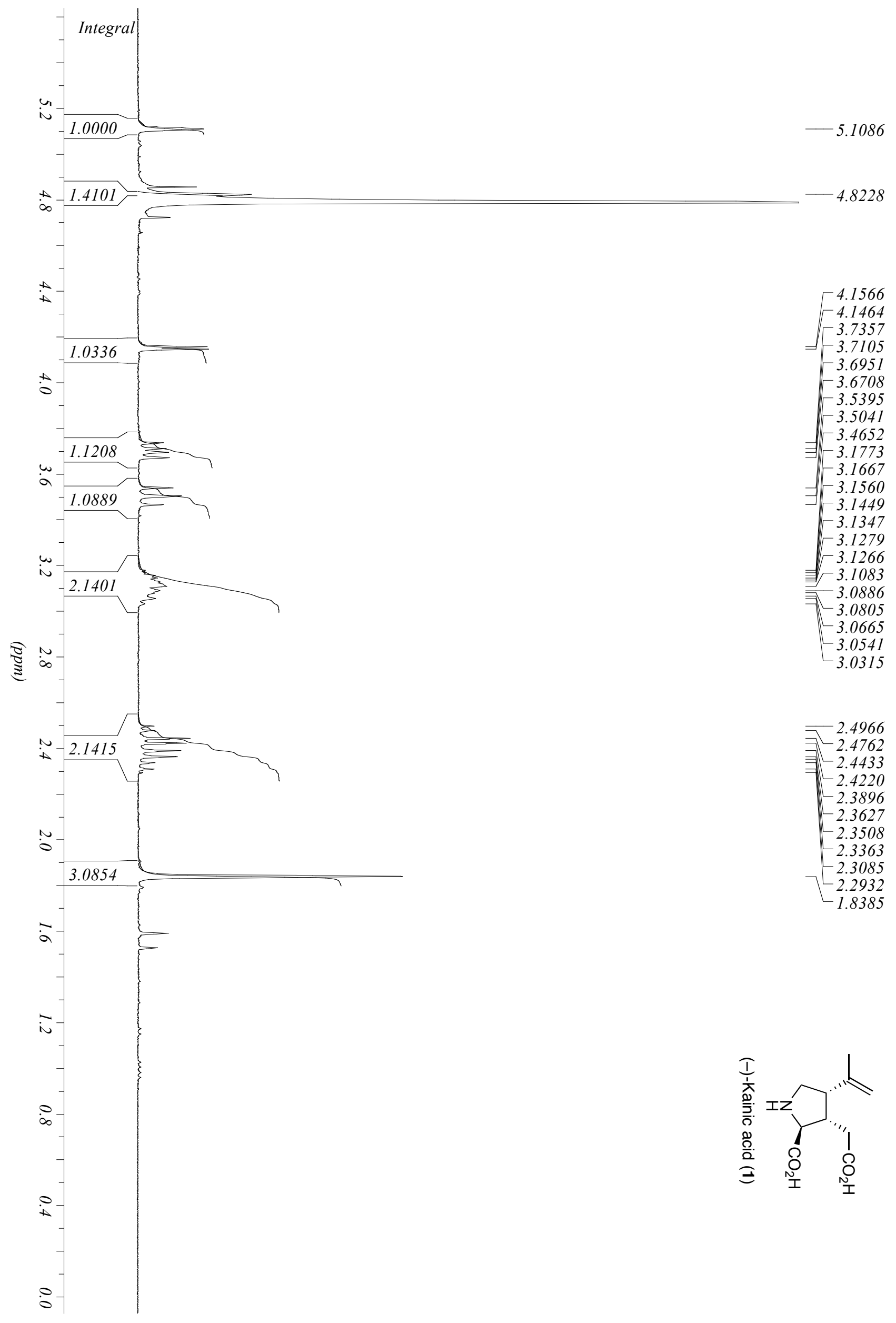




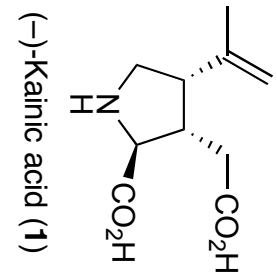

